\title{
Original Research and Review of Literature
}

\section{An inception cohort study of patients in a military clinic treated for lower back pain with lumbar fusion and SIGNAFUSE@ with a systematic review of the literature}

\author{
Adam J. Bevevino', Joshua P. Herzog ${ }^{2}$, Scott Seaman ${ }^{3}$ and R. Grant Steen ${ }^{4 *}$ \\ ${ }^{I}$ Department of Orthopaedic Surgery and Rehabilitation, William Beaumont Army Medical Center, El Paso, TX \\ ${ }^{2}$ OrthoVirginia, Richmond, VA \\ ${ }^{3}$ Research \& Development, Bioventus LLC \\ ${ }^{4}$ Department of Orthopaedic Surgery, Louisiana State University Medical Center, New Orleans, LA, Medical Affairs, Bioventus LLC, 4721 Emperor \\ Blvd., Suite 100, Durham, NC 27703
}

\section{ARTICLE INFO}

Article history:

Received Date: 30 November, 2018

Accepted Date: 11 December, 2018

Published Date: 31 December, 2018

\begin{abstract}
A B S T R A C T
Background: Use of synthetic bone graft substitutes for spinal fusion has increased sharply over the past 20 years. SIGNAFUSE® is one such synthetic graft material that provides an osteostimulatory effect for spinal fusion. Because clinical trials are not required for commercialization of synthetic bone graft substitutes in the United States, fusion rates attained using SIGNAFUSE for lumbar fusion are not well documented. The goal of the current study is to determine the rate of spinal fusion in a military clinic following lumbar fusion surgery augmented with SIGNAFUSE.

Methods: We report a retrospective chart review of 8 patients who received lumbar spinal fusion surgery augmented with SIGNAFUSE. All patients were assessed by computed tomographic (CT) imaging at least 1-year post-surgery to determine whether bony fusion had occurred. We also systematically reviewed literature sources that report fusion rate following spinal fusion surgery, for broader context.

Results: An average of 1.6 spinal levels were treated with SIGNAFUSE-loaded interbody cages. All patients had stabilization hardware via pedicle screws or integrated cage fixation. Seven of 8 patients successfully fused, for an overall fusion rate of $87.5 \%$ (95\% confidence interval: $47.4 \%$ to $99.7 \%$ ). Systematic review of 26 recent publications that included 1,126 patients treated with synthetic bone graft showed that the overall fusion rate in the literature is $84.4 \%$.

Conclusions: Fusion was achieved in $87.5 \%$ of patients treated with SIGNAFUSE. This is comparable to the fusion rate in a systematic review of 1,126 patients treated with synthetic bone graft materials.
\end{abstract}

\section{Introduction}

About two-thirds of adults have lower back pain (LBP) at some point during their lifetime [1]. LBP may be even more prevalent in a military population, due to acute trauma in combat and stress injuries in training [2]. LBP caused more than 457,000 Americans to seek spinal fusion in 2011 , with $\sim 75 \%$ of fusion procedures for spondylolisthesis, spondylosis, or other painful disk disorders [3, 4].
Lumbar fusion surgery is done to achieve solid fusion, restore spinal stability, and enable return to normal activities. Spinal fusion procedures use various biologic materials to promote new bone growth, with iliac crest bone graft (ICBG) considered the "gold standard" of treatment, because of its osteoconductivity, osteoinductivity, osteogenicity, and angiogenic potential $[5,6]$. Though ICBG is widely used, problems such as donor site morbidity, limited supply of graft material, potential increase in surgical complication rates, and the increase in surgical times

*Correspondence to: $R$. Grant Steen, Department of Orthopaedic Surgery, Louisiana State University Medical Center, New Orleans, LA Medical Affairs, Bioventus LLC, 4721 Emperor Blvd., Suite 100, Durham, NC 27703; E-mail: Grant.Steen@bioventusglobal.com 
argue against use of ICBG [5, 7]. Thus, there has been an effort to develop other bone grafting options that include allograft bone (e.g., demineralized bone matrices, allograft chips), synthetic graft materials (e.g. hydroxyapatite or HA), $\beta$-tricalcium phosphate ( $\beta$-TCP), bioactive glass, collagen-based matrix, or recombinant growth factors (e.g., rhBMP-2). Synthetic graft materials provide the osteoconductive element that ICBG provides but may lack the osteoinductive and osteogenic components of ICBG [6]. To circumvent these limitations, some synthetic grafts incorporate bioactive glass to provide an osteostimulatory signal and many surgeons combine synthetics with bone marrow aspirate (BMA), to provide an osteogenic component. Synthetic graft materials are attractive because of the low risk of disease transmission, minimal immunogenicity, and superior intra-operative handling capabilities [6]. Additionally, synthetics avoid the potential adverse events reported in some patients following use of rhBMP-2, including retrograde ejaculation, ectopic bone formation, and dysphagia $[8,9]$.

Here we report an inception cohort study of 8 patients treated in a military clinic who underwent lumbar fusion procedures to alleviate symptoms of degenerative disk disease and other spinal disorders. All patients were treated with SIGNAFUSE® Bioactive Bone Graft (Bioventus, Durham, NC), a combination synthetic graft composed of hydroxyapatite with $\beta$-tricalcium phosphate $(\mathrm{HA} / \beta-\mathrm{TCP})$ and bioactive glass in a resorbable polymer carrier, and all patients were evaluated for fusion by computed tomographic (CT) imaging. We also present a systematic review of publications reporting synthetic bone graft use in lumbar fusion surgery, as a point of comparison for our observed fusion results with SIGNAFUSE.

\section{Patients and Methods}

A planned retrospective chart review was combined with prospective computed tomographic (CT) imaging at follow-up, to evaluate the primary endpoint of radiographic fusion rate in patients treated with SIGNAFUSE at William Beaumont Army Medical Center (WBAMC) in El Paso, TX. The study received full Institutional Review Board (IRB) approval in October 2016. Potentially eligible patients were contacted after surgery by research staff to assess their interest in participating in the study. Patients were eligible for inclusion in this study if they:

- Were age 18 years of age or older;

- Were active duty military;

- Were a Department of Defense beneficiary;

- Had undergone a 1-3 level lumbar spinal fusion for a degenerative spinal process at WBAMC between August 2012 and January 2016;

- Voluntarily signed the IRB-approved informed consent document.

Patients were excluded from study if they:

- Were pregnant;

- Underwent lumbar spinal fusion surgery at 4 or more levels;

- Were diagnosed with concurrent tumor;

- Were indicated for surgery due to trauma;

- No longer resided in the WBAMC area.

Patients interested in the study were invited for an on-site visit with a follow-up CT scan at WBAMC. A total of 19 patients were consented for study participation; 8 patients met inclusion criteria and completed a follow-up CT scan. Fusion status of the patient was assessed using CT scans and the patients were considered fused if there was evidence of bilateral continuous trabecular bone across the fusion bed.

A systematic review was also performed to compare the observed healing outcomes to healing outcomes from a range of different spinal fusion techniques that used many different commercially available synthetic bone graft substitutes. Sources were identified by several PubMed searches, augmented with sources drawn from a recent systematic review [10]. We sought to identify lumbar fusion procedures that used a range of commercially available synthetic bone grafts. Specific inclusion criteria were that studies:

- Were identified using the search phrase "lumbar spinal fusion" or "lumbar spine fusion";

- Had been published within the last 20 years;

- Were randomized controlled trials (RCTs), prospective cohorts, or retrospective cohorts;

- Reported sufficient data to calculate fusion rate following fusion surgery;

- Used synthetic bone graft materials, bone grafts augmented with autograft, or bone marrow aspirate during the procedure;

- $\quad$ Assessed bony fusion by X-ray or CT;

- Were published in a peer-reviewed journal.

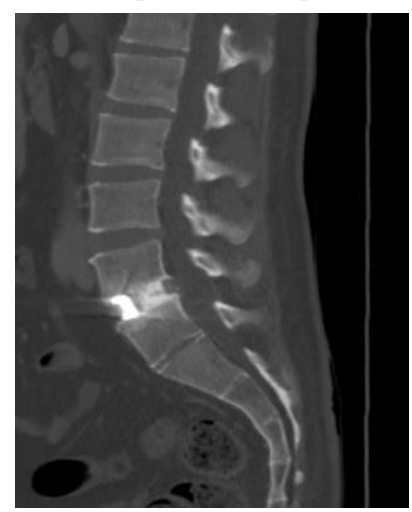

Figure 1: CT image for Patient \#3, acquired 1.8 years after surgery. Patient \#3 was a 34-year old male with a long history of lower back pain, beginning after an injury while on active-duty military service. His pain was midline in the lower back, with bilateral lower leg numbness and pain on the posterior aspect of both legs, with subjective muscle weakness. The patient was diagnosed with L5/S1 degenerative disc disease with herniation. The patient attempted conservative management, including physical therapy, pain medications, traction, and bracing, without relief, so he underwent an ALIF at L5/S1 without complication. Three months later, X-rays demonstrated L5/S1 incorporation of the graft into the endplates with bony fusion.

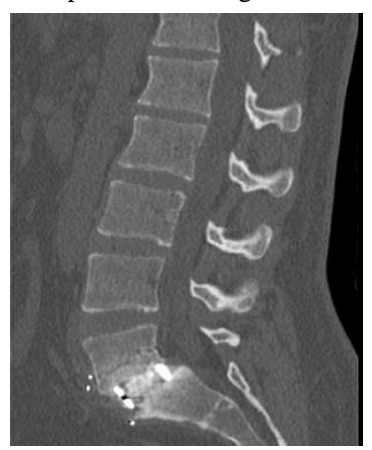

Figure 2: CT image for Patient \#12, acquired 1.6 years after surgery. Patient \#12 was a 25-year old male with bilateral leg pain and lower back pain of 2 years duration. Onset of pain was insidious, with no overt injury. Dorsal leg pain projected to the toes, with numbness and tingling, and patient had positional relief when leaning forward, but most other activities increased pain. Patient was diagnosed with L5/S1 spondylolisthesis with radiculopathy. The patient underwent an ALIF at L5/S1 without complication and CT scan demonstrated L5/S1 fusion of $40 \%$ of the disc at 20 months. 
Exclusion criteria (for the whole study or for a particular study arm) were that:

- Patient follow-up was less than 12 months;

- $\quad$ Surgery involved the cervical spine;

- $\quad$ Bone graft materials were augmented with rhBMP;

- Fusion was reported by level, not by patient;

- Radiographic assessment of fusion was not reported;

- Publication was as an abstract, conference proceeding, or editorial.

\section{Results}

Average patient age was 41.6 years (standard deviation $(\mathrm{SD})= \pm 10.6$ ) at surgery and 2 patients had prior surgery (Table 1). Diagnoses within the cohort included 6 patients with spondylosis and 2 with spondylolisthesis. In 5 patients, SIGNAFUSE was used in combination with bioglass granules and in 1 patient SIGNAFUSE was used in combination with cancellous allograft bone. Four patients received anterior lumbar interbody fusion (ALIF), 3 received transforaminal lumbar interbody fusion (TLIF), and 1 received oblique lumbar interbody fusion (OLIF) fusion surgery. An average of 1.6 spinal levels were fused (range: 1 to 3 levels). All patients received stabilization hardware via pedicle screw instrumentation or integrated fixation built into the ALIF cages (Table 2). Average duration of surgery was 181 minutes ( $\mathrm{SD}= \pm 94$ minutes), and operative blood loss was $164 \mathrm{~mL}$ ( \pm $260 \mathrm{~mL} \mathrm{SD}$ ). The average hospital stay after surgery was 2.1 days, with the longest stay being 3 days. Seven of 8 patients had successful fusion, as determined by $\mathrm{CT}$, for an overall fusion rate of $87.5 \%(95 \%$ confidence interval: $47.4 \%$ to $99.7 \%$ ) (Table 2). All 2- and 3-level fusion procedures showed evidence of radiographic fusion by CT scan within 2 years post-surgery, while 3 out of 4 patients with 1-level fusion procedures showed evidence of radiographic fusion. Figures 1 and 2 show representative CT scans of successfully fused patients.

A total of 26 published studies were identified for the systematic review (11-36). The process by which these studies were identified is shown (Figure 3). Included studies were predominantly posterolateral fusions (PLF) with instrumentation and used ceramic bone grafts augmented with autograft or bone marrow aspirate. Analysis of these published studies shows that the overall weighted average fusion rate is $84.4 \%$ in 1,126 patients (Table 3). Thus, fusion results from SIGNAFUSE-treated patients (Table 2) are comparable to fusion results in the systematic review (Table 3).

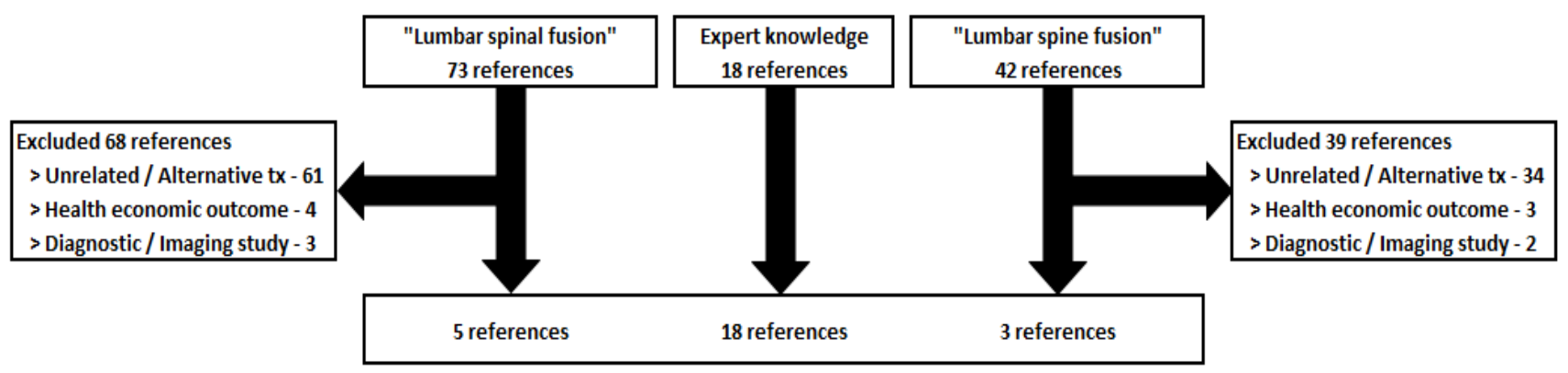

Figure 3: PRISMA diagram, showing how the sample of 26 studies reported in Table 3 was assembled.

Table 1: Patient demographics at surgery. DDD = Degenerative disk disease Spond $=$ Spondylolisthesis; LBP $=$ Lower back pain.

\begin{tabular}{|c|c|c|c|c|}
\hline Gender & Patient age & Pre-operative diagnosis & Pre-operative symptoms & Prior surgery \\
\hline Male & 42 & L3/L4, L4/L5 DDD & $\begin{array}{l}\text { LBP, anterolateral right thigh pain, left thigh } \\
\text { pain }\end{array}$ & None \\
\hline Male & 33 & L5/S1 DDD, herniation & $\begin{array}{l}\text { LBP for } 13 \text { years, bilateral lower leg } \\
\text { numbness, muscle weakness }\end{array}$ & None \\
\hline Male & 41 & L4/L5 DDD, L5/S1 Spond & $\begin{array}{l}\text { LBP for } 2 \text { years, right leg numbness, right leg } \\
\text { tingling, right leg pain }\end{array}$ & None \\
\hline Male & 25 & L5/S1 Spond, radiculopathy & $\begin{array}{l}\text { LBP for }>2 \text { years, bilateral leg pain, bilateral } \\
\text { leg numbness, bilateral leg tingling }\end{array}$ & None \\
\hline Male & 55 & L4/L5, L5/S1 DDD & $\begin{array}{l}\text { LBP for } 30 \text { years, right foot numbness, right } \\
\text { lower leg numbness }\end{array}$ & None \\
\hline Male & 42 & L4/L5 DDD, herniated disc & $\begin{array}{l}\text { LBP for } 5 \text { years, bilateral lower extremity } \\
\text { pain }\end{array}$ & None \\
\hline Female & 38 & L5/S1 Synostosis & $\begin{array}{l}\text { LBP for }>5 \text { years, } \mathrm{L} 5 / \mathrm{S} 1 \text { synchondosis, right } \\
\text { leg pain, right foot pain }\end{array}$ & L4/L5 ALIF \\
\hline Male & 57 & L3/L4, L4/L5, L5/S1 DDD & $\begin{array}{l}\text { Back pain for }>1 \text { year, right lower extremity } \\
\text { tingling for }>1 \text { year }\end{array}$ & $\begin{array}{l}\text { L4/L5 } \\
\text { microdiscectomy }\end{array}$ \\
\hline
\end{tabular}


Table 2: Operative characteristics and outcomes. INTERFACE $=$ synthetic granules (45S5 bioglass) ALIF $=$ anterior lumbar interbody fusion; TLIF $=$ transforaminal lumbar interbody fusion; OLIF = oblique lumbar interbody fusion.

\begin{tabular}{|c|c|c|c|c|c|c|c|c|}
\hline Fusion levels & $\begin{array}{l}\text { Surgical } \\
\text { Technique }\end{array}$ & $\begin{array}{l}\text { SIGNAFUSE } \\
\text { graft used }\end{array}$ & $\begin{array}{l}\text { Other graft } \\
\text { used }\end{array}$ & $\begin{array}{l}\text { Spinal } \\
\text { levels } \\
\text { fused }\end{array}$ & $\begin{array}{l}\text { Operative } \\
\text { time (min) }\end{array}$ & $\begin{array}{l}\text { Operative } \\
\text { blood loss } \\
(\mathrm{mL})\end{array}$ & $\begin{array}{l}\text { Hospital } \\
\text { stay } \\
\text { (days) }\end{array}$ & Outcome \\
\hline L3/L4, L4/L5 & ALIF & $15 \mathrm{~g}$ & $\begin{array}{l}\text { INTERFACE } \\
1 \mathrm{~g}\end{array}$ & 2 & 160 & 100 & 3 & Fused \\
\hline L5/S1 & ALIF & $15 \mathrm{~g}$ & $\begin{array}{l}\text { INTERFACE } \\
1 \mathrm{~g}\end{array}$ & 1 & 105 & 50 & 2 & Fused \\
\hline L4/5, L5/S1 & ALIF & $15 \mathrm{~g}$ & $\begin{array}{l}\text { INTERFACE } \\
1 \mathrm{~g}\end{array}$ & 2 & 273 & 75 & 3 & Fused \\
\hline L5/S1 & ALIF & $15 \mathrm{~g}$ & $\begin{array}{l}\text { INTERFACE } \\
1 \mathrm{~g}\end{array}$ & 1 & 104 & 20 & 2 & Fused \\
\hline L4/L5, L5/S1 & TLIF & $7.5 \mathrm{~g}$ & $\begin{array}{l}\text { Cancellous } \\
\text { chips } 30 \text { cc }\end{array}$ & 2 & 232 & 50 & 2 & Fused \\
\hline L4/L5 & TLIF & $15 \mathrm{~g}$ & None & 1 & 83 & NA & 1 & Not Fused \\
\hline L5/S1 & TLIF & $15 \mathrm{~g}$ & None & 1 & 143 & 100 & 2 & Fused \\
\hline \multirow[t]{3}{*}{$\mathrm{L3} / 4, \mathrm{~L} 4 / 5, \mathrm{~L} 5 / \mathrm{S} 1$} & OLIF & $30 \mathrm{~g}$ & $\begin{array}{l}\text { INTERFACE } \\
1 \mathrm{~g}\end{array}$ & 3 & 347 & 750 & 2 & Fused \\
\hline & & Average & & 1.6 & 180.9 & 163.6 & 2.1 & $87.5 \%$ fused \\
\hline & & SD & & 0.7 & 94.0 & 260.2 & 0.6 & $35.4 \%$ \\
\hline
\end{tabular}

\section{Discussion}

Our results show that a fusion rate of $87.5 \%$ can be attained in a clinical setting with a range of different lumbar fusion approaches combined with SIGNAFUSE (Table 2). The fusion rates obtained with SIGNAFUSE are thus comparable to fusion rates reported with a range of other synthetic bone grafts (Table 3). The overall weighted average of fusion in the 26 publications was $84.4 \%$ (943 of 1,126 patients fused), while the fusion success of our SIGNAFUSE-treated patients was $87.5 \%$ (7 of 8 patients fused). Sub-analysis of the systematic review by graft type (HA, $\beta$-TCP, or HA/ $\beta$-TCP) showed that fusion rates did not differ appreciably, with respective average fusion rates of $80 \%, 86 \%$, and $88 \%$ (Table 3).

This study has several limitations. First, the number of patients in our series is small, and patients were treated with several different surgical techniques, while most published studies were PLF procedures. Second, varying amounts of SIGNAFUSE graft material were used (range: 7.5 $30 \mathrm{~g}$ ) in our series (Table 2). Third, the systematic review reports a range of different synthetic graft materials which may not all be comparable to one another, but the sample size of the individual graft materials is too small to analyze separately. Fourth, even within the cohort of patients who received SIGNAFUSE, some patients had SIGNAFUSE augmented with bioactive glass, some patients had SIGNAFUSE augmented with cancellous chips, and some patients did not have any supplemental grafting materials. Fifth, the volume and relative ratio of other materials (BMA, autograft, etc.) mixed with graft materials varied, so it is not possible to attribute fusion success to any specific synthetic materials. For example, one study used HA and $\beta$-TCP without other supplemental grafting materials, while all other studies in the systematic review used BMA or autograft to augment the synthetic materials [33]. Finally, few controlled trials using synthetic bone graft materials have been conducted overall, so there is a compelling need for additional research.

\section{Conclusions}

Lumbar fusion surgery has increased in the recent past and is expected to continue to increase as the population ages [4]. Stable fusion is the goal of surgery, so there is a strong impetus to identify which types of bone grafting materials or bone graft substitutes are most effective in attaining fusion. The use of a synthetic graft such as SIGNAFUSE, alone or in combination with other grafting materials, may provide an advantage in spinal fusion surgery.

Table 3: Systematic review of previously published studies utilizing synthetic bone grafts in lumbar fusion approaches $\mathrm{HA}=$ hydroxyapatite; $\beta$-TCP = beta-tricalcium phosphate; $\mathrm{A}=$ autograft $\mathrm{BMA}=$ bone marrow aspirate; $\beta$-TCS $=$ beta-tricalcium sulfate; $\mathrm{C}=$ collagen; $\mathrm{DBM}=$ demineralized bone matrix; $\mathrm{Si}-\mathrm{CaP}=$ silicate substituted calcium phosphate.

\begin{tabular}{|c|c|c|c|c|c|c|c|c|c|}
\hline First Author & Year & Ref \# & Design & Approach & Graft & FU (mos) & Patients & Fused & Fusion rate (\%) \\
\hline Cavagna & 1999 & 11 & Prosp. & PLF & $H A+\beta-T C P+A+B M A$ & 24 & 106 & 100 & 94 \\
\hline \multirow[t]{2}{*}{ Chen } & 2005 & 12 & Retro. & PLF & $\beta-\mathrm{TCS}+\mathrm{A}$ & 30 & 39 & 34 & 87 \\
\hline & 2005 & 12 & Retro. & PLF & $\beta-\operatorname{TCS}(S)+A$ & 30 & 35 & 29 & 83 \\
\hline Hsu & 2005 & 13 & Prosp. & PLF & $H A+A$ & 12 & 38 & 25 & 66 \\
\hline Korovessis & 2005 & 14 & RCT & PLF & $H A+A+B M A$ & 12 & 38 & 38 & 100 \\
\hline Kanayama & 2006 & 15 & RCT & PLF & $H A+\beta-T C P+A$ & 12 & 10 & 9 & 90 \\
\hline Kitchel & 2006 & 16 & Prosp. & PLF + PLIF & $H A+C+B M A$ & 24 & 25 & 20 & 80 \\
\hline \multirow[t]{3}{*}{ Neen } & 2006 & 17 & Prosp. & PLF & $\mathrm{HA}+\mathrm{C}+\mathrm{BMA}$ & 24 & 15 & 14 & 93 \\
\hline & 2006 & 17 & Prosp. & PLIF & $H A+C+B M A$ & 24 & 13 & 11 & 85 \\
\hline & 2006 & 17 & Prosp. & ALIF & $\mathrm{HA}+\mathrm{C}+\mathrm{BMA}$ & 24 & 22 & 17 & 77 \\
\hline Moro-Barrero & 2007 & 18 & Prosp. & PLF & $H A+\beta-T C P+A$ & 30 & 35 & 31 & 89 \\
\hline Chang & 2008 & 19 & Retro. & PLF & $\beta-\mathrm{TCS}+A$ & 12 & 66 & 61 & 92 \\
\hline Dai & 2008 & 20 & RCT & PLF & $\beta-T C P+A$ & 12 & 32 & 32 & 100 \\
\hline Epstein & 2008 & 21 & Prosp. & PLF & $\beta-\mathrm{TCP}+\mathrm{A}+\mathrm{BMA}$ & 24 & 60 & 51 & 85 \\
\hline Epstein & 2009 & 22 & Prosp. & PLF & $\beta-T C P+A+B M A$ & 12 & 100 & 95 & 95 \\
\hline
\end{tabular}




\begin{tabular}{|c|c|c|c|c|c|c|c|c|c|}
\hline First Author & Year & Ref \# & Design & Approach & Graft & FU (mos) & Patients & Fused & Fusion rate (\%) \\
\hline Niu & 2009 & 23 & Prosp. & PLF & $\beta-T C S+B M A$ & 24 & 22 & 10 & 45 \\
\hline Jenis & 2010 & 24 & Retro. & PLF & $\mathrm{HA}+\mathrm{BMA}$ & 24 & 42 & 34 & 81 \\
\hline Ploumis & 2010 & 25 & $\mathrm{RCT}$ & PLF & $\mathrm{HA}+\mathrm{C}+\mathrm{BMA}+\mathrm{A}$ & 24 & 12 & 11 & 92 \\
\hline Park & 2011 & 26 & Retro. & PLF & $\beta-T C P+A$ & 12 & 30 & 25 & 83 \\
\hline Yamada & 2012 & 27 & Prosp. & PLF & $\beta-\mathrm{TCP}+\mathrm{A}+\mathrm{BMA}$ & 24 & 61 & 57 & 93 \\
\hline Kong & 2013 & 28 & Prosp. & PLF & $\beta-T C P+A$ & 12 & 42 & 24 & 57 \\
\hline Kunakornsawat & 2013 & 29 & Retro. & PLF & $\mathrm{HA}+\mathrm{C}+\mathrm{BMA}$ & 24 & 27 & 8 & 30 \\
\hline Pimenta & 2013 & 30 & $\mathrm{RCT}$ & XLIF & Si-CaP & 12 & 13 & 7 & 54 \\
\hline Yoo & 2015 & 31 & Retro. & TLIF & $H A+A$ & 24 & 77 & 67 & 87 \\
\hline Nam & 2016 & 32 & Prosp. & PLF & $H A+A$ & 12 & 41 & 30 & 73 \\
\hline Parker & 2016 & 33 & Prosp. & XLIF & $H A+\beta-T C P$ & 24 & 25 & 20 & 80 \\
\hline Epstein & 2017 & 34 & Prosp. & PLF & $H A+C+A+B M A$ & 37 & 59 & 57 & 97 \\
\hline Gatam & 2017 & 35 & Prosp. & TLIF & $\mathrm{HA}+\mathrm{DBM}$ & 12 & 17 & 13 & 76 \\
\hline \multirow[t]{2}{*}{ vonderHoeh } & 2017 & 36 & RCT & TLIF & $\mathrm{HA}+\mathrm{A}$ & 12 & 24 & 20 & 83 \\
\hline & & & & & Average $=$ & 20.1 & 1126 & 950 & 84.4 \\
\hline
\end{tabular}

\section{REFERENCES}

1. Lipson SJ (2004) Spinal-fusion surgery advances and concerns. $N$ Engl J Med 350: 643-644. [Crossref]

2. Halvarsson A, Hagman I, Tegern M, Broman L, Larsson H (2018) Selfreported musculoskeletal complaints and injuries and exposure of physical workload in Swedish soldiers serving in Afghanistan. PLoS One 13 :e0195548. [Crossref]

3. Andersson G, Watkins-Castillo SI (2014) The Burden of Musculoskeletal Diseases in the United States: Spinal Fusion.

4. Deyo RA, Nachemson A, Mirza SK (2004) Spinal-fusion surgery - the case for restraint. $N$ Engl J Med 350: 722-726. [Crossref]

5. Kannan A, Dodwad SN, Hsu WK (2015) Biologics in spine arthrodesis. $J$ Spinal Disord Tech 28: 163-170. [Crossref]

6. Rolvien T, Barbeck M, Wenisch S, Amling M, Krause M (2018) Cellular Mechanisms Responsible for Success and Failure of Bone Substitute Materials. Int J Mol Sci 19: E2893. [Crossref]

7. Agarwal R, Williams K, Umscheid CA, Welch WC (2009) Osteoinductive bone graft substitutes for lumbar fusion: a systematic review. JNeurosurg Spine 11: 729-740. [Crossref]

8. Carragee EJ, Hurwitz EL, Weiner BK (2011) A critical review of recombinant human bone morphogenetic protein-2 trials in spinal surgery: emerging safety concerns and lessons learned. Spine J 11: 471491. [Crossref]

9. Fu R, Selph S, McDonagh M, Peterson K, Tiwari A, et al. (2013) Effectiveness and harms of recombinant human bone morphogenetic protein-2 in spine fusion: a systematic review and meta-analysis. Ann Intern Med 158: 890-902. [Crossref]

10. Buser Z, Brodke DS, Youssef JA, Meisel HJ, Myhre SL, et al. (2016) Synthetic bone graft versus autograft or allograft for spinal fusion: a systematic review. J Neurosurg Spine 25: 509-516. [Crossref]

11. Cavagna R, Daculsi G, Bouler JM (1999) Macroporous calcium phosphate ceramic: a prospective study of 106 cases in lumbar spinal fusion. J Long Term Eff Med Implants 9: 403-412. [Crossref]

12. Chen WJ, Tsai TT, Chen LH, Niu CC, Lai PL, et al. (2005) The fusion rate of calcium sulfate with local autograft bone compared with autologous iliac bone graft for instrumented short-segment spinal fusion. Spine 30: 2293-2297. [Crossref]

13. Hsu CJ, Chou WY, Teng HP, Chang WN, Chou YJ (2005) Coralline hydroxyapatite and laminectomy-derived bone as adjuvant graft material for lumbar posterolateral fusion. J Neurosurg Spine 3: 271-275. [Crossref]

14. Korovessis P, Koureas G, Zacharatos S, Papazisis Z, Lambiris E (2005) Correlative radiological, self-assessment and clinical analysis of evolution in instrumented dorsal and lateral fusion for degenerative lumbar spine disease. Autograft versus coralline hydroxyapatite. Eur Spine J 14: 630-638. [Crossref]

15. Kanayama M, Hashimoto T, Shigenobu K, Yamane S, Bauer TW, et al. (2006) A prospective randomized study of posterolateral lumbar fusion using osteogenic protein-1 (OP-1) versus local autograft with ceramic bone substitute: emphasis of surgical exploration and histologic assessment. Spine 31: 1067-1074. [Crossref]

16. Kitchel SH (2006) A preliminary comparative study of radiographic results using mineralized collagen and bone marrow aspirate versus autologous bone in the same patients undergoing posterior lumbar interbody fusion with instrumented posterolateral lumbar fusion. Spine $J$ $6:$ 405-411. [Crossref]

17. Neen D, Noyes D, Shaw M, Gwilym S, Fairlie N, et al. (2006) Healos and bone marrow aspirate used for lumbar spine fusion: a case controlled study comparing healos with autograft. Spine 31: 636-640. [Crossref]

18. Moro-Barrero L, Acebal-Cortina G, Suárez-Suárez M, Pérez-Redondo J, Murcia Mazón A, et al. (2007) Radiographic analysis of fusion mass using fresh autologous bone marrow with ceramic composites as an alternative to autologous bone graft. J Spinal Disord Tech 20: 409-415. [Crossref]

19. Chang CH, Lin MZ, Chen YJ, Hsu HC, Chen HT (2008) Local autogenous bone mixed with bone expander: an optimal option of bone graft in single-segment posterolateral lumbar fusion. Surg Neurol 25: S183-S189. [Crossref]

20. Dai LY, Jiang LS (2008) Single-level instrumented posterolateral fusion of lumbar spine with beta-tricalcium phosphate versus autograft: a prospective, randomized study with 3-year follow-up. Spine 33: 12991304. [Crossref]

21. Epstein NE (2008) An analysis of noninstrumented posterolateral lumbar fusions performed in predominantly geriatric patients using lamina autograft and beta tricalcium phosphate. Spine J 8: 882-887. [Crossref]

22. Epstein NE (2009) Beta tricalcium phosphate: observation of use in 100 posterolateral lumbar instrumented fusions. Spine $J$ 9: 630-638. [Crossref]

23. Niu CC, Tsai TT, Fu TS, Lai PL, Chen LH, et al. (2009) A comparison of posterolateral lumbar fusion comparing autograft, autogenous laminectomy bone with bone marrow aspirate, and calcium sulphate with bone marrow aspirate: a prospective randomized study. Spine 34: 27152719. [Crossref]

24. Jenis LG, Banco RJ (2010) Efficacy of silicate-substituted calcium phosphate ceramic in posterolateral instrumented lumbar fusion. Spine 35: 1058-1063. [Crossref]

25. Ploumis A, Albert TJ, Brown Z, Mehbod AA, Transfeldt EE (2010) Healos graft carrier with bone marrow aspirate instead of allograft as adjunct to local autograft for posterolateral fusion in degenerative lumbar 
scoliosis: a minimum 2-year follow-up study. J Neurosurg Spine 13: 211215. [Crossref]

26. J H Park, C G Choi, S R Jeon, S C Rhim, C J Kim, et al. (2011) Radiographic Analysis of Instrumented Posterolateral Fusion Mass Using Mixture of Local Autologous Bone and b-TCP (PolyBone ${ }^{\circledR}$ ) in a Lumbar Spinal Fusion Surgery. J Korean Neurosurg Soc 49: 267-272. [Crossref]

27. Yamada T, Yoshii T, Sotome S, Yuasa M, Kato T, et al. (2012) Hybrid grafting using bone marrow aspirate combined with porous $\beta$-tricalcium phosphate and trephine bone for lumbar posterolateral spinal fusion: a prospective, comparative study versus local bone grafting. Spine 37: 174179. [Crossref]

28. Kong S, Park JH, Roh SW (2013) A prospective comparative study of radiological outcomes after instrumented posterolateral fusion mass using autologous local bone or a mixture of beta-tcp and autologous local bone in the same patient. Acta Neurochir 155: 765-770. [Crossref]

29. Kunakornsawat S, Kirinpanu A, Piyaskulkaew C, Sathira-Angkura V (2013) A comparative study of radiographic results using HEALOS collagen-hydroxyapatite sponge with bone marrow aspiration versus local bone graft in the same patients undergoing posterolateral lumbar fusion. J Med Assoc Thai 96: 929-935. [Crossref]

30. Pimenta L, Marchi L, Oliveira L, Coutinho E, Amaral R (2013) A prospective, randomized, controlled trial comparing radiographic and clinical outcomes between stand-alone lateral interbody lumbar fusion with either silicate calcium phosphate or rh-BMP2. J Neurol Surg A Cent Eur Neurosurg 74: 343-350. [Crossref]
31. Yoo JS, Min SH, Yoon SH (2015) Fusion rate according to mixture ratio and volumes of bone graft in minimally invasive transforaminal lumbar interbody fusion: minimum 2-year follow-up. Eur J Orthop Surg Traumatol 1: S183-S189. [Crossref]

32. Nam WD, Yi J (2016) Bone Union Rate Following Instrumented Posterolateral Lumbar Fusion: Comparison between Demineralized Bone Matrix versus Hydroxyapatite. Asian Spine J 10: 1149-1156. [Crossref]

33. Parker RM, Malham GM (2017) Comparison of a calcium phosphate bone substitute with recombinant human bone morphogenetic protein-2: a prospective study of fusion rates, clinical outcomes and complications with 24-month follow-up. Eur Spine $J$ 26: 754-763. [Crossref]

34. Epstein NE (2017) High lumbar noninstrumented fusion rates using lamina autograft and Nanoss/bone marrow aspirate. Surg Neurol Int 8:153. [Crossref]

35. A R Gatam, L Gatam, S Lumban Tobing (2017) Comparison of Clinical and Radiological Outcomes of Lumbar Interbody Fusion Using a Combination of Hydroxyapatite and Demineralized Bone Matrix and Autografts for Lumbar Degenerative Spondylolisthesis. Asian Spine J 11: 706-714. [Crossref]

36. vonderHoeh NH, Voelker A, Heyde CE (2017) Results of lumbar spondylodeses using different bone grafting materials after transforaminal lumbar interbody fusion (TLIF). Eur Spine $J$ 26: 2835 2842. [Crossref] 